\title{
Kinetic study of the effect of kiwi fruit actinidin on various proteins of chicken meat
}

\author{
Sara BAGHERI KAKASH ${ }^{1}$, Mohammad HOJJATOLESLAMY²* (D), Ghobad BABAEI ${ }^{3}$, Hooman MOLAVI $^{4}$
}

\begin{abstract}
In this research, the effect of kiwi protein on the physicochemical properties of chicken meat was investigated (Ross breed). Chicken thighs have been marinated in the form of cubes with dimensions of $2 \mathrm{~cm}$ in $20 \mathrm{~mL}$ of kiwi protein with activity of $0.9 \mathrm{u} / \mathrm{mL}$ for $2,4,6,8,24,48,72$, and $96 \mathrm{hr}$, and kept in a refrigerator at $4 \pm 1{ }^{\circ} \mathrm{C}$. Then, the enzyme actinidin was inactivated at $60{ }^{\circ} \mathrm{C}$ for $10 \mathrm{~min}$, and the samples were evaluated. The results showed that the kiwi protein had a significant effect on the punch force, springiness, and chewiness of the chicken meat samples, and the reduced hardness was due to the activity of photolytic enzymes on myofibrillar proteins, and breaking the connective tissues. Muscle hydrolysis and release of amino acids significantly reduced $\mathrm{pH}$ in the treated samples compared to control. The affecting time of the enzyme had a significant effect on the degradation of meat proteins; it increased the solubility and hydrolysis degree, and reduced the average peptide chain length. The marination of chicken in kiwi increased lightness significantly $(\mathrm{p}<0.05)$.
\end{abstract}

Keywords: chicken proteins; kiwi; hydrolysis degree; peptide chain length.

Practical Application: Improvement of industrial properties of chicken meat for industrial consumption.

\section{Introduction}

In recent years, poultry meat, as a source of animal protein, has been widely used in human nutrition; and in some countries, facing a shortage in terms of nature and rangeland conditions, poultry meat has rapidly replaced other kinds of meat. The digestibility and absorbability of chicken meat in terms of protein and interactions of essential amino acids, are not lower than those of beef, mutton, and pork, with the exception that its cholesterol level is lower, and its tissue is easier to digest than other kinds of meat (Beyki Bandarabadi, 2005). Tenderness of meat is in general considered one of the most important factors affecting the quality of meat. Physical and chemical methods are typically used to improve the tenderness of meat. All these methods focus on decreasing and/or degrading myofibrillar proteins and connective tissues. Muscle foods are traditionally marinated in acidic solutions such as acetic acid or lactic acid to make meat soft and tasty (Berge et al., 2001). Treatment with external proteases is one of the most effective methods used to tenderize meat. Proteases such as plant-derived bromelain, papain, and ficin are widely used to tenderize meat (Koak et al., 2011; Ha et al., 2012). Actinidin is a protein with a molecular weight of 30,000 Daltons, which is extracted from edible kiwifruit. It is part of the family of sulfhydryl proteases such as papain; and similar to papain, it is a meat-tenderizing enzyme, but it is more effective in tenderizing food than other sulfhydryl proteases (El-Gharbawi \& Whitaker, 2006; Gilman et al., 1946). Using this enzyme in meat tenderizing prevents the creation of soft and viscous texture on the meat surface, noticed in meats tenderized by other tenderizing enzymes such as papain (Lewis \& Luh, 1988; Kowlessur et al., 1989). In addition, actinidin is used as a food digestive aid. Actinidin is usually used as a protease in compounds produced to help digest food, especially in people who have digestive problems such as intestinal inflammation. The other advantage of this enzyme over papain, as a protease, is that it is active within the thermal range of $2-45^{\circ} \mathrm{C}$, which is much lower than the appropriate temperature for the activity of papain, which is between $60-70{ }^{\circ} \mathrm{C}$ (Lewis \& Luh, 1988; Carne \& Moore, 1978). Since 1991, some researchers have studied the effect of different plant enzymes on different types of meat through the immersion method, and have found out that fruits such as pineapple, ginger, kiwi, figs, and papaya increased the tenderness of beef, and improved the aroma and flavor of the product (Garg \& Mendiratta, 2006; Han et al., 2009; Naveena et al., 2004; Toohey et al., 2011; Wada et al., 2002). The herbal proteases present in these fruits increase tenderness in the tissues of such kinds of meat by affecting myofibrillar proteins and connective tissues, degradation of actomyosin and, to some extent, degradation of elastin and collagen (due to their collagenase and elastase contents) (Lawrie \& Ledward, 2006). These enzymes are thiol, cysteine or sulfhydryl proteins, which hydrolyze peptide, ester, and amide bonds. The catalytic action of these enzymes takes place in two stages. The first stage is acylation, during which an intermediate enzyme-acyl compound is produced, and the second stage is the separation of the part containing the acyl from the enzyme, which is accompanied by the hydrolysis of the intermediate compound and production of the product (Tarté, 2009; Polaina \& MacCabe, 2007). Given the importance of actinidin among proteases, the effect of kiwi protein on the 
physicochemical properties of chicken meat (Ross breed) has been studied.

\section{Materials and methods}

\subsection{Extraction of kiwi protein}

Extraction was carried out according to a method devised by Paul et al. (1995) with some minor changes. Ten grams of peeled kiwi were mashed in liquid nitrogen using a pestle and mortar. Next, an extraction buffer containing $150 \mu \mathrm{L}$ of $100 \mathrm{mM}$ phosphate buffer $(\mathrm{pH}=6)$ from $\mathrm{L}(+) 10 \mathrm{mM}$ ascorbic acid and $5 \mathrm{mM}$ EDTA was added to bring the final volume to $12 \mathrm{~mL}$. Then, it was centrifuged at $4000 \mathrm{rpm}$ at $4{ }^{\circ} \mathrm{C}$ for $10 \mathrm{~min}$, and the supernatant was stored at $-20^{\circ} \mathrm{C}$. To minimize proteinase activity, the whole extraction process was carried out on ice (Afshar-Mohammadian et al., 2011). The concentration of kiwi protein was measured through the Bradford method.

\subsection{Determination of the proteolytic activity}

The solutions and buffers used to determine the protease activity included a 0.05 molar phosphate buffer $(\mathrm{pH}=7.2)$, a phosphate-cysteine-EDTA buffer solution with a $\mathrm{pH}=6(7.1 \mathrm{~g}$ of anhydrous dibasic sodium phosphate, $14 \mathrm{~g}$ of dihydrate sodium EDTA, and $6.1 \mathrm{~g}$ of monohydrate cysteine hydrochloride to prepare 1 liter of the buffer), a $30 \%$ trichloroacetic acid solution, a casein substrate solution (a $1 \%$ casein solution in a 0.05 molar phosphate buffer), and a papain stock solution (100 mg of USP papain with an activity of $3 \mathrm{U} / \mathrm{mg}$ in $100 \mathrm{~mL}$ of phosphate-cysteine-EDTA buffer solution). Dilutions of 2, 4, 6, 8, 10, 12, 14, 16, 18 and $20 \mathrm{mg}$ in $100 \mathrm{~mL}$ of phosphate-cysteine-EDTA buffer solution were made from the papain stock solution (Englund et al., 1968). 5 milliliters of a $1 \%$ casein solution was poured into each test tube (10 test tubes were blank test tubes, and 10 standard test tubes). The specimens were put in a warm-water bath at $40^{\circ} \mathrm{C}$ for $15 \mathrm{~min}$. After temperature equilibration, 2 milliliters of papain dilutions were added to each of the standard test tubes. First, 3 milliliters of trichloroacetic acid solution, and then, 2 milliliters of papain dilutions were added to the 10 control test tubes, which were incubated in a $40{ }^{\circ} \mathrm{C}$ bath for $60 \mathrm{~min}$. During this time, the tubes were shaken several times in the bath. Over time, the contents of the standard tubes gradually became milkier and more opaque, indicating the enzymatic hydrolysis of casein by the enzyme papain. After the $60 \mathrm{~min}$ duration was over, the reaction in the standard tubes was stopped by adding three milliliters of the trichloroacetic acid solution. The tubes were placed in a $40^{\circ} \mathrm{C}$ bath for another $30 \mathrm{~min}$ to ensure the coagulation of all the proteins. Protein clots were filtered through a Whatman No. 42 filter paper. The absorption rates of the solutions at $280 \mathrm{~nm}$ in the standard tubes were read in front of their corresponding blank tubes, and the relationship of the absorption rate at $280 \mathrm{~nm}$ with the concentration and activity of papain was determined (Englund et al., 1968). The activity of kiwi was determined using the standard chart plotted for the activity of papain. The activity of the kiwi being used was $0.9 \mathrm{u} / \mathrm{mg}$.

\subsection{Preparation and marination}

After chickens were slaughtered, the chicken meat was kept at $4{ }^{\circ} \mathrm{C}$ for $24 \mathrm{hr}$. After separating the superficial layers of fat, the chicken thighs were cut into cubes with dimensions of $2 \mathrm{~cm}$ using a knife. Then, each slice of meat was placed in a bag made of polyethylene with dimensions of $8 \times 12 \mathrm{~cm}^{2}$. An amount of $20 \mathrm{~mL}$ of kiwi (Hayward) protein with an activity of $0.9 \mathrm{u} / \mathrm{mg}$ was added to each slice of meat, and the slices of meat were kept in an immersed form in a refrigerator at $4 \pm 1{ }^{\circ} \mathrm{C}$. After $2,4,6,8$, $24,48,72$, and $96 \mathrm{hr}$, hydrolysis was stopped for $10 \mathrm{~min}$ at $60^{\circ} \mathrm{C}$.

\subsection{Investigating the physicochemical properties}

\section{The texture test}

Texture is a sensory feature; therefore, only one human being (or an animal, in case of animal food) can describe and understand it. Instrumental texture tests can only identify and measure certain physical parameters, which must then be interpreted with sensory perception (Szczesniak, 2002; Amirpur, 2013).

In order to evaluate the textural properties, texture profile analysis and punch test 2, 4, 6, 8, 24, 48, 72 and $96 \mathrm{hrs}$ after the addition of kiwi protein to the meat has been performed. In order to evaluate the texture tests, Brookfield texture analyzer model: CT3-4300 at a speed of $0.5 \mathrm{~mm} / \mathrm{s}$, a sensitivity or loading rate of $6.8 \mathrm{~g}$, and samples of meat in the form of cubes with dimensions of $2 \times 2 \times 2 \mathrm{~cm}^{3}$. A cylindrical TA/1000 probe with a diameter of $25.4 \mathrm{~mm}$ was used in the texture profile analysis, a TA/39 probe with a diameter of $2 \mathrm{~mm}$ was used in the punch test, and each test was carried out for at least seven iterations.

\section{Color evaluation}

Color changes in the treated samples compared in order to investigate the effect of the actinidin present in the kiwi protein using a ColorFlex colorimeter through the HunterLab measurement system. Each test was performed in three iterations. The values of the hue indices: $\mathrm{a}^{\star}$ (redness), $\mathrm{b}^{*}$ (yellowness), and $\mathrm{L}^{*}$ (lightness), were determined by placing the samples inside the tank of the apparatus (Burke \& Monahan, 2003; Ergezer \& Gokce, 2011; Hinkle et al., 2010). The parameter $c^{\star}$ or chroma (the saturation or purity of a color) was obtained by transforming the Cartesian coordinates $\left(\mathrm{a}^{*}, \mathrm{~b}^{*}\right)$ into the polar coordinates based on the Equation 1 (Zardetto \& Dalla Rosa, 2006):

$c^{*}=\sqrt{\left(a^{*}\right)^{2}+\left(b^{*}\right)^{2}}$

The Equation 2 was used to calculate the colorimetric difference $(\Delta E)$ and the hue angle for each sample (Zardetto \& Dalla Rosa, 2006; Equation 3):

$$
\begin{aligned}
& \Delta \mathrm{E}=\sqrt{\left(\Delta L^{*}\right)^{2}+\left(\Delta a^{*}\right)^{2}+\left(\Delta b^{*}\right)^{2}} \\
& \operatorname{Arctan}\left(\frac{b^{*}}{a^{*}}\right)=\text { Hue index }
\end{aligned}
$$


pH

The $\mathrm{pH}$ values of the samples were directly measured using a Testo $230 \mathrm{pH}$ meter.

\subsection{Extraction of the total protein}

The total protein (sarcoplasmic + myofibrillar) was extracted through a method devised by Joo et al. (1999). 40 milliliters of 0.1 molar phosphate buffer $(\mathrm{pH}=7.2)$ containing 1.1 molar potassium iodide was added to two grams of ground meat. The sample was homogenized and then centrifuged at $1500 \times \mathrm{g}$ at $4{ }^{\circ} \mathrm{C}$ for $20 \mathrm{~min}$. Afterwards, the supernatant (the total protein area) was transferred to new microtubes, and was kept there at $-20^{\circ} \mathrm{C}$ until use. The protein concentration in the supernatant was measured using the Biuret method (Joo et al., 1999).

\subsection{Extraction of sarcoplasmic proteins}

A method devised by Molina \& Toldrá (1992) was used to extract sarcoplasmic proteins. First, $20 \mathrm{~g}$ of the ground meat sample was mixed with $200 \mathrm{~mL}$ of a $0.02 \mathrm{M}$ phosphate buffer $(\mathrm{pH}=7.4)$ in the proportion of $1: 10$. Then, the mixture was homogenized, and centrifuged at $15770 \times \mathrm{g}$ at $4{ }^{\circ} \mathrm{C}$ for $20 \mathrm{~min}$. Afterwards, the supernatant (the sarcoplasmic area) was sterilized by filtration with a $0.22 \mu \mathrm{m}$ filter, and was kept at $-20^{\circ} \mathrm{C}$ until use. The protein concentration in the supernatant was measured using the Biuret method (Molina \& Toldrá, 1992).

\subsection{Extraction of myofibrillar proteins}

Myofibrillar proteins were extracted using a method devised by Claeys et al. (1995). Twenty-five grams of ground meat was mixed with $25 \mathrm{~mL}$ of a buffer solution $\left(3^{\circ} \mathrm{C}, \mathrm{pH}=7.6\right)$ containing 0.25 molar sucrose, $0.05 \mathrm{M}$ tris, and $1 \mathrm{mM} \mathrm{EDTA}^{1}$; and the mixture was then homogenized using a homogenizer at a speed of $16000 \times \mathrm{rpm}$ for $30 \mathrm{sec}$. The homogenized mixture was then centrifuged at a force of $1000 \times \mathrm{g}$ for 10 mines. After pouring the solution away, the solid portion was again mixed with $25 \mathrm{~mL}$ of the buffer solution $\left(3^{\circ} \mathrm{C}, \mathrm{pH}=7.6\right)$ containing $0.05 \mathrm{M}$ tris and $1 \mathrm{mM}$ EDTA, and after vortexing, the mixture was centrifuged at a force of $1000 \times \mathrm{g}$ for 10 mines; then, the supernatant liquid was poured away. For the third time, the extraction was performed with $25 \mathrm{~mL}$ of a (cold) $0.15 \mathrm{M} \mathrm{KCl}$ solution. The resulting deposition, which was in fact isolated myofibrillar proteins, was kept in $10 \mathrm{~mL}$ of an $\mathrm{MFI}^{2}$ buffer (100 mM potassium chloride, $20 \mathrm{mM}$ potassium phosphate $(\mathrm{pH}=7), 1 \mathrm{mM}$ EDTA, $1 \mathrm{mM}$ magnesium chloride, and $1 \mathrm{mM}$ sodium azide (Claeys et al., 1995). The concentrations of the extracted proteins were measured through the Biuret method.

\subsection{Determining the degree of hydrolysis}

The degree of hydrolysis was determined based on a method devised by Adler-Nissen (1986). O-phthaldialdehyde (OPA) indicators have to be prepared on a daily basis. An amount of $620.7 \mathrm{~g}$ Sodium tetraborate along with 10 molecules of water and

\footnotetext{
1 Ethylenediaminetetraacetic acid.

2 Myofibrillar Fragmentation Index.
}

$200 \mathrm{~mL}$ of sodium dodecyl sulfate (SDS) was dissolved in $150 \mathrm{~mL}$ of water. One hundred sixty milligrams of $97 \%$ o-phthaldialdehyde (OPA) was dissolved in $4 \mathrm{~mL}$ of ethanol, and was added to the previous solution. Then, $400 \mu \mathrm{L}$ of $\beta$-mercaptoethanol was also added, and the total volume was brought to $200 \mathrm{~mL}$ with distilled water. After extracting myofibrillar, sarcoplasmic, and total proteins from the control sample, the proteins were dried using a freeze dryer. Next, $0.1 \mathrm{~g}$ of the proteins was dissolved in distilled water, and the concentrations of the proteins were measured using the Biuret method. Afterwards, the solution was pasteurized at $85^{\circ} \mathrm{C}$ for 3 mines, and then it was cooled down to the hydrolysis temperature $\left(50^{\circ} \mathrm{C}\right)$. Before the addition of the enzyme, the $\mathrm{pH}$ of the solution was adjusted to 8 using a 4 normal sodium hydroxide solution, and the kiwi protein was added to the solution by an amount equal to $2 \%$ of the concentration of meat proteins. After 2, 4, 6, 8, 24, 48, 72, and $96 \mathrm{hrs}$, the reaction was stopped for 10 mines through heating at $60^{\circ} \mathrm{C}$. Then, $400 \mu \mathrm{L}$ of the hydrolyzed protein samples was mixed with $3 \mathrm{~mL}$ of an OPA reagent for 5 seconds. After being kept at room temperature for 2 mines, the absorption rate at a wavelength of $340 \mathrm{~nm}$ was read (the standard being used was serine). The degree of hydrolysis (DH) was calculated through the following Equations 4 and 5:

degree of hydrolysis $=h / h_{\text {tot }} \times 100 \%$

$h=\operatorname{serin}-\mathrm{NH}_{2}-\beta / \alpha$

\subsection{Determination of the average peptide chain length}

The average peptide chain length (PCL) was calculated for the hydrolyzed protein samples through the following Equation 6 (Marambe et al., 2008):

Average peptide chain length $=100 / D H$

\subsection{Enzymatic hydrolysis kinetics}

There are two approaches to finding out the rate of a reaction; one is measuring the concentration of substrate in the medium (s) and the other is measuring the concentration of product of the reaction (p) resulted from effect of enzyme. However, the second generally leads to more precise results. In the systems which are composed of an enzyme and a substrate, changes in substrate concentration during the time is initially constant and then it reduces as the time goes and the concentration of the substrate decreases (Fatemi, 2016). A major criterion of measuring enzyme activity is to determine its kinetics characteristics of a reaction, since it is a systematic method for analysis and quantitative measuring of the effect of factors such as enzyme concentration, substrate concentration, temperature and $\mathrm{pH}$ on enzyme activity. Michaelis-Menten equation is the simplest way for finding out the enzymatic kinetics. A relation was obtained between rate of product formation (catalyst velocity), substrate and enzyme concentrations (Mortazavi et al., 2007). To study the effect of concentrations of enzyme and substrate on the enzymatic reaction, different concentrations of substrate $(18-45 \mathrm{mg} / \mathrm{mL})$ with a certain $0.7 \mu \mathrm{g} / \mathrm{mL}$ enzyme concentration and different enzyme concentrations $(0.8-1.4 \mathrm{mg} / \mathrm{mL})$ with a certain substrate concentration were prepared and then degree of hydrolysis was measured using Adler-Nissen (1986) method with ortho-phthal- 
dialdehyde indicator, during the time. All experiments were performed in the conditions at $50{ }^{\circ} \mathrm{C}$ in six replications.

\subsection{Statistical analysis}

All the experiments were carried out in six iterations. The test data were analyzed in a completely randomized design at a statistical level of 95\% using the SPSS software version 22 . The means of the data were compared based on Duncan's multiple range test at a significant level of $95 \%$. All charts were plotted by Excel.

\section{Results and discussion}

\subsection{The effect of kiwi on the texture}

According to Figure 1, the kiwi protein has had a significant effect $(\mathrm{p}<0.05)$ on the punch force in the chicken meat samples. The reduction in the punch force can be due to the effect of the enzyme actinidin, present in the kiwifruit, on myofibrillar proteins and connective tissues, resulting in the tenderness of meat. The kiwi protein has had no significant effect $(\mathrm{p}<0.05)$ on hardness in the chicken samples. Hardness decreased in all
A

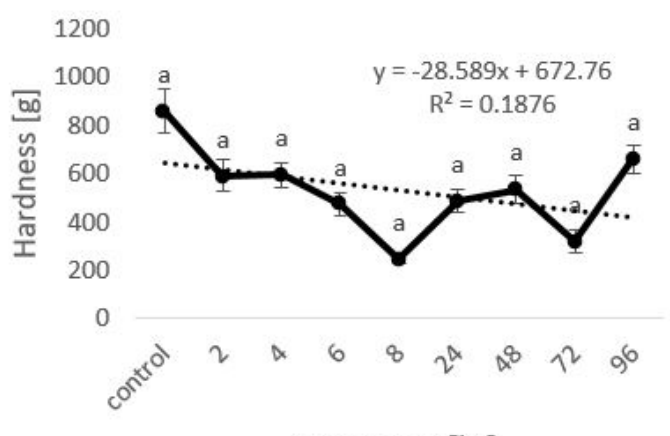

Treatment $[\mathrm{hr}]$

C

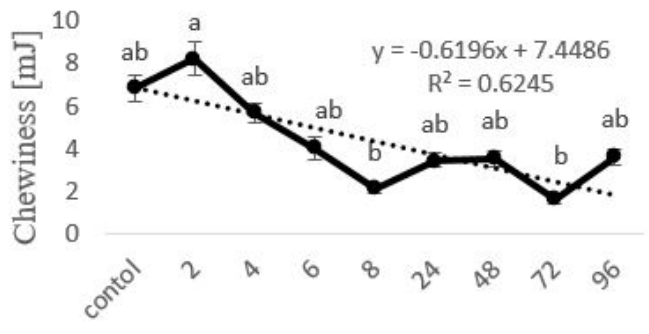

Treatment $[\mathrm{hr}]$
B

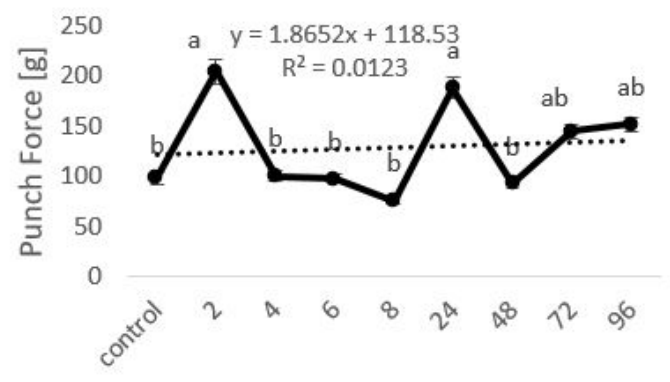

Treatment [hr]

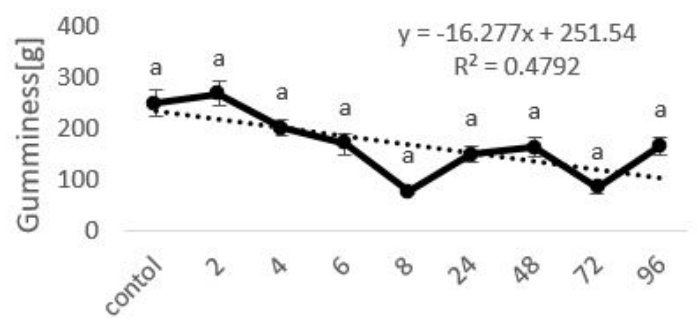

Treatment $[\mathrm{hr}]$

$E$

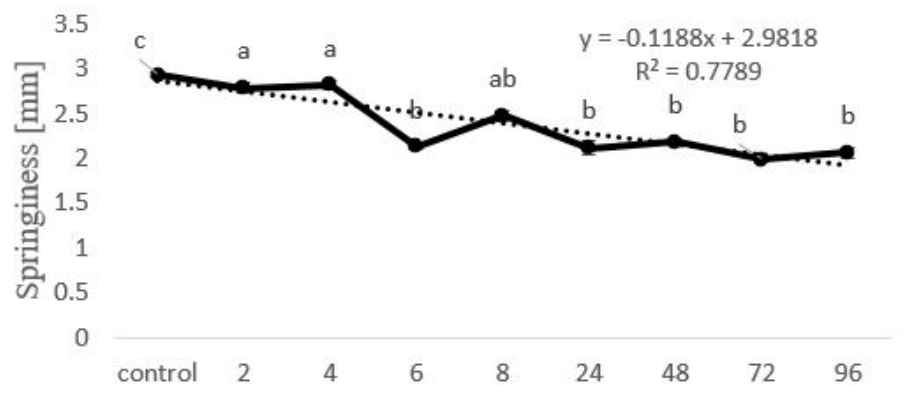

Treatment $[\mathrm{hr}]$

Figure 1. The Effect of kiwi Protein on the Texture of Chicken Meat, (A) Hardness; (B) Punch Force; (C) Chewiness; (D) Gumminess; (E) Springiness. 
the treated samples compared to that in the control sample. The reduction in hardness was due to the activity of proteolytic enzymes on myofibrillar proteins, and breaking the connective tissues. Myosin is the main and most abundant protein in the muscle. Any change in the myosin molecule can affect the texture and water-holding capacity of meat. Given that the anatomical position of muscles in livestock also affects the softness and delicacy of meat, and there can even be a difference between different parts of a muscle in terms of softness (Noordahr, 1998), it may also be for this reason that the treated samples differ in terms of reduction in hardness. Samejima et al. (1991) observed that in non-thermal conditions, actinidin caused the tenderness of tissue through digesting insoluble collagen and elastin and, to some extent, degrading the connective tissues (Wada et al., 2004). When the breakdown of myofibrillar proteins occurs, small peptides with a low molecular weight are produced, reducing the hardness of the meat sample (Rawdkuen et al., 2013). According to Koak et al. (2011), tissue hardness decreased by $50 \%$ when $50 \%(\mathrm{w} / \mathrm{w})$ of kiwifruit was used in the beef sample. Hardness is determined by measuring intramuscular connective tissues, intramuscular fat, and sarcomere length (Kemp \& Parr, 2012). Proteolytic enzymes; especially herbal proteases, are widely used to tenderize meat (Ha et al., 2012; Ketnawa \& Rawdkuen, 2011; Sullivan \& Calkins, 2010). Ha et al. (2012) observed that actinidin protease had the greatest effect on the hydrolysis of myofibrillar proteins, whereas ginger protease was more effective in the analysis of connective tissues. The kiwi protein has had no significant effect $(\mathrm{p}<0.05)$ on the gumminess of the chicken samples. Since gumminess is the product of two factors; hardness and cohesiveness, as the hardness of the meat samples resulting from the effect of kiwi protein decreases, the energy required to disintegrate the meat samples, to make them ready for swallowing, decreases, too (Hellyer, 2004; Bourne, 2002; Brookfield, 2007). According to Figure 1, the kiwi protein has had a significant effect $(\mathrm{p}<0.05)$ on springiness in the meat samples, and has reduced springiness in the chicken samples, compared to that in the control sample. This reduction was due to the effect of kiwi on meat proteins and degradation of proteins. The kiwi protein has had a significant effect $(\mathrm{p}<0.05)$ on chewiness in the meat samples. Since chewiness is the product of two factors; gumminess and springiness, due to the reduced gumminess and springiness of meat, which is the result of the activity of the enzyme actinidin present in kiwi protein, the energy required to masticate meat, to make it ready for swallowing, decreases, as well (Hellyer, 2004; Bourne, 2002; Brookfield, 2007).

\section{2 $p H$ changes}

According to Table 1, the $\mathrm{pH}$ value was higher in the control sample than in the other treatments, which was due to the higher initial $\mathrm{pH}$ of meat in the control sample. A significant decrease was observed in the $\mathrm{pH}$ values of the treatments compared to that of the control sample, which was due to the lower initial $\mathrm{pH}$ of kiwi protein in the treatments than in the control sample. The hydrolysis of the muscle can lead to the release of amino acids, and reduce the $\mathrm{pH}$. According to an investigation carried out by Ketnawa \& Rawdkuen (2011), using bromelain extract reduced $\mathrm{pH}$ in treated samples compared to that in the control sample. The $\mathrm{pH}$ value is very important in meat products, and has a major impact on qualitative and physicochemical properties such as water-holding capacity, tenderness, and juiciness (Goli et al., 2007). Changes in $\mathrm{pH}$ are caused by postmortem metabolism, as well as using substances added to meat during technological processes (Gault, 1985).

\subsection{Results of evaluating hue indices}

By referring to Table 1, it was observed that marination of chicken meat in kiwi had a significant effect $(p<0.05)$ on the lightness factor, and that the lightness factor increased in kiwi-treated chicken meat compared to that in the control sample. According to presented reports, above the isoelectric point, the appearance of meat seems darker due to increased negative charges and protein repulsion. However, at the isoelectric point, as the positive and negative charges are at equilibrium, and due to the attraction force between proteins, the light is reflected and the appearance of the meat seems lighter (Hinkle et al., 2010). On the other hand, studies show that reducing $\mathrm{pH}$ below the isoelectric point results in denaturation of sarcoplasmic and myofibrillar proteins, thus increasing water-holding capacity in them. The amount of water present between muscle fibers, and how it is dispersed can affect reflectivity in the meat in a way that lightness decreases (Aktaş \& Kaya, 2001). The increase in lightness can be due to the increased light reflection by denatured proteins, and the denaturation of myoglobin by actinidin. kiwi has a significant effect $(\mathrm{p}<0.05)$ on the following factors: a,b,and $\Delta \mathrm{E}$.

Table 1. Comparison of the mean effects of kiwi protein at different times on the lightness of meat samples $p<0.05$. All values are the mean \pm standard error.

\begin{tabular}{|c|c|c|c|c|c|c|c|}
\hline Treatment & $\mathrm{pH}$ & $\mathrm{L}^{*}$ & $\mathrm{a}^{*}$ & $\mathrm{~b}^{*}$ & $\mathrm{c}$ & $\Delta \mathrm{E}$ & Hue \\
\hline control & 5.9 & $24.60^{c} \pm 4.22$ & $16.10^{\mathrm{a}} \pm 2.30$ & $9.18^{\mathrm{a}} \pm 1.50$ & $14.78^{\mathrm{a}} \pm 1.84$ & $0.00^{\mathrm{b}}$ & $29.89^{c} \pm 6.53$ \\
\hline $2 \mathrm{hr}$ & 4.9 & $28.56^{\mathrm{ab}} \pm 2.86$ & $11.89^{b} \pm 1.67$ & $10.44^{\mathrm{a}} \pm 2.01$ & $7.01^{\mathrm{de}} \pm 2.44$ & $7.51^{\mathrm{a}} \pm 2.74$ & $41.10^{\mathrm{ab}} \pm 3.52$ \\
\hline $4 \mathrm{hr}$ & 4.44 & $25.82^{b c} \pm 2.51$ & $10.62^{b} \pm 3.83$ & $5.87^{\mathrm{b}} \pm 1.34$ & $8.52^{\mathrm{cd}} \pm 3.97$ & $8.11^{\mathrm{a}} \pm 3.68$ & $29.89^{c} \pm 4.49$ \\
\hline $6 \mathrm{hr}$ & 4.3 & $30.43^{\mathrm{a}} \pm 0.17$ & $10.49^{b} \pm 3.53$ & $7.49^{\mathrm{ab}} \pm 1.79$ & $6.85^{\mathrm{ef}} \pm 3.90$ & $9.59^{\mathrm{a}} \pm 2.65$ & $36.34^{\mathrm{ab}} \pm 3.49$ \\
\hline $8 \mathrm{hr}$ & 4.21 & $30.45^{\mathrm{a}} \pm 2.15$ & $10.84^{\mathrm{b}} \pm 1.31$ & $7.79^{\mathrm{ab}} \pm 3.76$ & $8.92^{c} \pm 3.15$ & $9.19^{\mathrm{a}} \pm 4.69$ & $33.64^{\mathrm{ab}} \pm 11.24$ \\
\hline $24 \mathrm{hr}$ & 4.17 & $28.46^{\mathrm{ab}} \pm 1.41$ & $11.09^{b} \pm 2.24$ & $7.16^{\mathrm{ab}} \pm 2.60$ & $5.58^{\mathrm{f}} \pm 3.02$ & $9.11^{\mathrm{a}} \pm 2.23$ & $31.82^{\mathrm{bc}} \pm 7.75$ \\
\hline $96 \mathrm{hr}$ & 4.04 & $30.41^{\mathrm{a}} \pm 2.05$ & $11.98^{\mathrm{b}} \pm 1.12$ & $10.32^{\mathrm{a}} \pm 1.09$ & $8.49^{\mathrm{cd}} \pm 1.02$ & $7.69^{\mathrm{a}} \pm 4.68$ & $40.73^{\mathrm{ab}} \pm 4.45$ \\
\hline
\end{tabular}

$\mathrm{a}^{*}=$ redness; $\mathrm{b}^{*}=$ yellowness; $\mathrm{L}^{*}=$ lightness; $\mathrm{c}=$ chroma; $\Delta \mathrm{E}=$ colorimetric difference; Hue $=$ hue angle. 
The redness of samples marinated with kiwi has decreased relative to that of the control sample. It is likely that reducing $\mathrm{pH}$ below the isoelectric point results in the denaturation of sarcoplasmic proteins, thus reducing the redness of samples (Aktaş \& Kaya, 2001; Önenc et al., 2004; Serdaroğlu et al., 2007). The $a^{\star}$ value is dependent on the contents of pigments and myoglobin, and iron concentrations. Therefore, a changes in $\mathrm{a}^{*}$ value is dependent on the myoglobin content that might undergo oxidation to form metmyoglobin, resulting in the appearance of more brownishness in color (Chueachuaychoo et al., 2011). Formation of metmyoglobin is the reason the meat color changes from red into brownish green (Page et al., 2001). The hue angle is an indicator of the food color. Zero and/or 360 degrees represent the red color, and the angles: 90, 180, and 270 degrees represent yellow, green, and blue, respectively. By referring to the ANOVA table, it was observed that marination of meat with kiwi had a significant effect $(\mathrm{p}<0.05)$ on the hue angle, and increased it. Among all the treatments, the lowest hue angle value belonged to the control sample. Chroma (the saturation of a color) is a criterion which shows the difference of a color from the gray color, and is defined as the purity criterion. By referring to the ANOVA table, it was observed that marination of meat with kiwi had a significant effect $(\mathrm{p}<0.05)$ on chroma, and reduced chroma in comparison to that in the control sample.

\subsection{Protein solubility}

According to Table 2 and Figure 2, the higher protein solubility values were observed in all enzyme treated samples compared to the control. The higher activity of the enzyme and/or the longer duration of its contact with the substrate cause(s) further hydrolysis, and increase(s) solubility. The production efficiency of soluble nitrogen (soluble protein) can generally be increased by increasing the activity of proteolytic enzymes. If the concentration of the substrate exceeds a certain limit (> 8\%), the rate of hydrolysis will decrease (Kristinsson \& Rasco, 2000). Changes in protein solubility can be due to the degradation of myofibrillar proteins; and the increase in the solubility of enzyme-treated samples can be due to the increased permeability

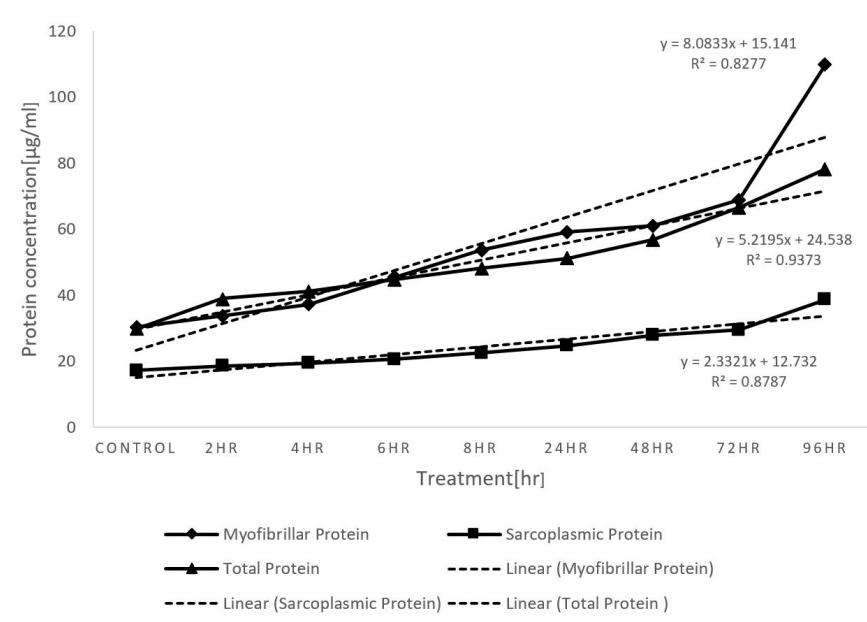

Figure 2. The Effect of kiwi on changes in the concentration of chicken protein. of myofibrils, which can be easily decomposed. The difference in protein solubility can be due to the difference in the structure of meat (Rawdkuen et al., 2013).

\subsection{Determining the degree of hydrolysis}

The first and most important property of a hydrolyzed protein is its degree of hydrolysis. As can be seen in Table 3 and charts in Figure 3, as the time increases, the degree of hydrolysis increases. In fact, it can be said that with an increase in the time

Table 2. The Effect of kiwi on changes in the concentration of chicken protein. All values are the mean \pm standard error.

\begin{tabular}{cccc}
\hline Treatmen & $\begin{array}{c}\text { concentration } \\
\text { of total proteins } \\
(\mu \mathrm{g} / \mathrm{mL})\end{array}$ & $\begin{array}{c}\text { concentration } \\
\text { of myofibrillar } \\
\text { proteins }(\mu \mathrm{g} / \mathrm{mL})\end{array}$ & $\begin{array}{c}\text { concentration } \\
\text { of sarcoplasmic } \\
\text { proteins }(\mu \mathrm{g} / \mathrm{mL})\end{array}$ \\
\hline Control & $29.87 \pm 0.01$ & $30.51 \pm 0.01$ & $17.26 \pm 0.00$ \\
$2 \mathrm{hrs}$ & $39.05 \pm 0.01$ & $33.87 \pm 0.00$ & $18.64 \pm 0.00$ \\
$4 \mathrm{hrs}$ & $41.22 \pm 0.00$ & $37.22 \pm 0.02$ & $19.39 \pm 0.00$ \\
$6 \mathrm{hrs}$ & $44.80 \pm 0.01$ & $45.43 \pm 0.01$ & $20.62 \pm 0.00$ \\
$8 \mathrm{hrs}$ & $48.12 \pm 0.00$ & $53.64 \pm 0.02$ & $22.63 \pm 0.00$ \\
$24 \mathrm{hrs}$ & $51.18 \pm 0.01$ & $59.24 \pm 0.01$ & $24.72 \pm 0.01$ \\
$48 \mathrm{hrs}$ & $56.78 \pm 0.01$ & $61.14 \pm 0.00$ & $27.93 \pm 0.01$ \\
$72 \mathrm{hrs}$ & $66.51 \pm 0.02$ & $68.87 \pm 0.02$ & $29.61 \pm 0.00$ \\
$96 \mathrm{hrs}$ & $78.19 \pm 0.03$ & $110.10 \pm 0.06$ & $38.72 \pm 0.02$ \\
\hline
\end{tabular}

Table 3. Results corresponding to the hydrolysis degree and average peptide chain length of the total protein.

\begin{tabular}{cccc}
\hline Protein type & Time & DH & PCL \\
\hline Total proteins & $2 \mathrm{hrs}$ & $0.76 \pm 0.02$ & $131.66 \pm 4.44$ \\
& $4 \mathrm{hrs}$ & $0.93 \pm 0.02$ & $107.12 \pm 4.13$ \\
& $6 \mathrm{hrs}$ & $0.99 \pm 0.01$ & $101.16 \pm 1.84$ \\
& $8 \mathrm{hrs}$ & $1.00 \pm 0.01$ & $99.77 \pm 1.90$ \\
& $24 \mathrm{hrs}$ & $1.03 \pm 0.01$ & $96.69 \pm 2.36$ \\
& $48 \mathrm{hrs}$ & $3.06 \pm 0.00$ & $32.63 \pm 0.12$ \\
& $72 \mathrm{hrs}$ & $3.20 \pm 0.01$ & $31.21 \pm 0.20$ \\
Myofibrillar & $96 \mathrm{hrs}$ & $3.25 \pm 0.01$ & $30.78 \pm 0.22$ \\
proteins & $2 \mathrm{hrs}$ & $1.50 \pm 0.02$ & $66.60 \pm 2.42$ \\
& $4 \mathrm{hrs}$ & $2.28 \pm 0.02$ & $43.85 \pm 0.84$ \\
& $6 \mathrm{hrs}$ & $2.32 \pm 0.01$ & $43.04 \pm 0.74$ \\
& $8 \mathrm{hrs}$ & $2.91 \pm 0.02$ & $34.39 \pm 0.67$ \\
& $24 \mathrm{hrs}$ & $3.13 \pm 0.01$ & $31.99 \pm 0.36$ \\
Sarcoplasmic & $48 \mathrm{hrs}$ & $3.24 \pm 0.01$ & $30.86 \pm 0.36$ \\
proteins & $72 \mathrm{hrs}$ & $3.35 \pm 0.01$ & $29.81 \pm 0.18$ \\
& $96 \mathrm{hrs}$ & $5.33 \pm 0.11$ & $18.77 \pm 1.17$ \\
& $4 \mathrm{hrs}$ & $1.91 \pm 0.01$ & $52.32 \pm 0.92$ \\
& $6 \mathrm{hrs}$ & $2.45 \pm 0.01$ & $40.84 \pm 0.92$ \\
& $8 \mathrm{hrs}$ & $2.69 \pm 0.01$ & $38.32 \pm 0.55$ \\
& $24 \mathrm{hrs}$ & $3.25 \pm 0.18$ & $37.19 \pm 0.38$ \\
& $48 \mathrm{hrs}$ & $3.25 \pm 0.01$ & $30.78 \pm 0.25$ \\
& $72 \mathrm{hrs}$ & $3.37 \pm 0.12$ & $29.64 \pm 2.79$ \\
& $96 \mathrm{hrs}$ & $4.43 \pm 0.08$ & $22.58 \pm 1.25$ \\
\hline
\end{tabular}

All values are the mean \pm standard error; $\mathrm{DH}=$ Degree of hydrolysis; $\mathrm{PCL}=$ Average peptide chain length. 


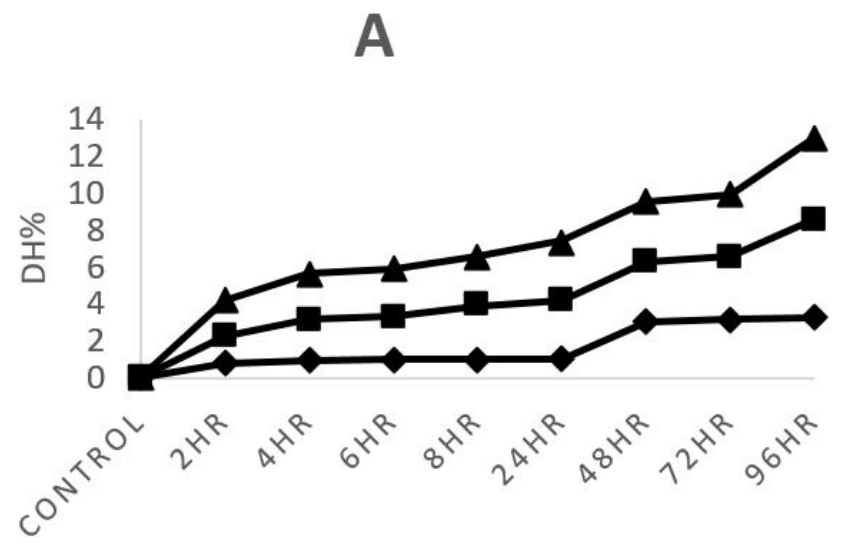

Tratment[hr]

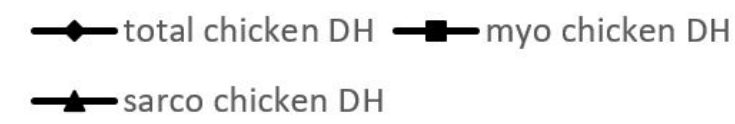

B
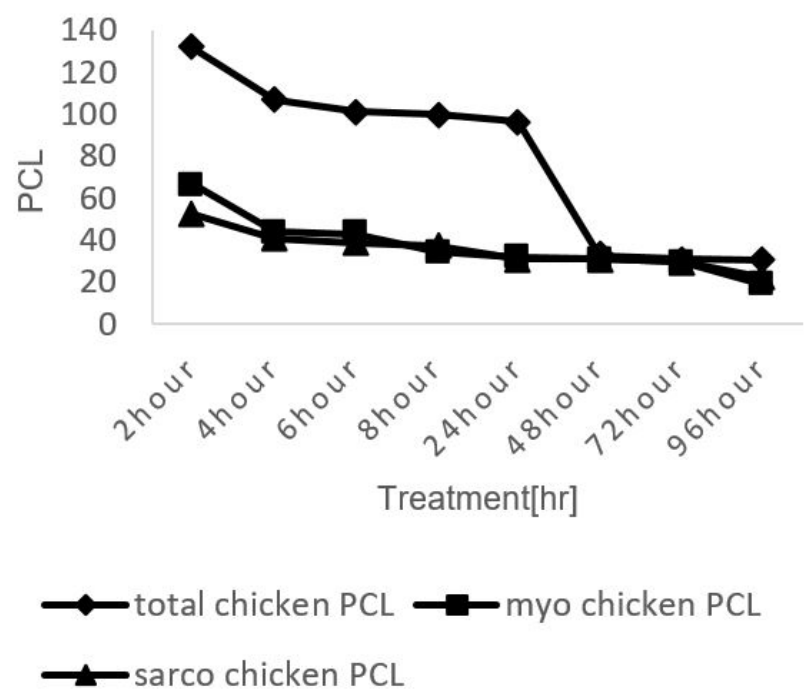

Figure 3. Changes in the degree of hydrolysis and average peptide chain length in chicken versus the time of the hydrolysis process. (A) degree of hydrolysis; (B) average peptide chain length.

of hydrolysis, the enzyme and substrate will be near each other for a longer duration, and the intensity of hydrolysis will increase. Liaset et al. (2000) showed that an increase in the hydrolysis time increased the degree of hydrolyzing salmon using the enzyme alcalase. A similar result was also obtained by Souissi et al. (2007) about the offal of sardines. Motamedzadegan et al. (2009) also showed that an increase in the affecting time of the enzyme papain increases the hydrolysis degree of myofibrillar proteins in the Caspian tyulka. Many researchers like Ovissipour et al. (2010), Cao et al. (2008), Shahidi et al. (1995), and Kristinsson \& Rasco (2000), too, showed that an increase in the time of hydrolysis increased the degree of hydrolysis, and confirmed the obtained result. Another property of hydrolyzed proteins is the length of peptides produced by the hydrolysis. The degree of hydrolysis is inversely related to the peptide chain length; that is to say, with an increase in the degree of hydrolysis, the average peptide chain length decreases.

\subsection{Effect of different substrate and enzyme concentration of enzymatic reaction}

Figure 4 shows that the degree of hydrolysis reduced by increasing the concentration of substrate from 18 to $45 \mathrm{mg} / \mathrm{mL}$. Thus, it can be concluded that substrate is not only able to enhance reaction rate in low concentrations, but also can restrain enzyme activity in higher concentrations. In enzymatic hydrolysis, choosing an optimum substrate concentration can improve catalytic efficiency of enzyme and reduce production costs as well as preserving reaction at high rates and not inhibiting enzyme activity. Effect of different concentrations of enzyme on enzymatic reaction is presented in Figure 5. According to the results, degree of hydrolysis increased considerably as the concentration of the enzyme increased from 0.8 to $1.4 \mathrm{mg} / \mathrm{mL}$.
In practical conditions, a low enzyme concentration should be chosen so that degree of hydrolysis is controlled well and the catalyst cost is lowered at the same time (Qian et al., 2011). Same results were obtained for sardine (Quaglia \& Orban, 1987), shark (Kristinsson, 1998), crab (Baek \& Cadwallader, 1995), menhaden (Hevia et al., 1976), calf bone (Linder et al., 1995), whey protein (Mutilangi et al., 1995) and casein (Mahmoud et al., 1992).

As the results presented in Figure 4 and 5 suggest, degree of hydrolysis increased at the first stage of time and then reached to a constant value with direct and reverse relation to enzyme and substrate concentration, respectively. Reaction rate reduced during time, especially at middle and final stage which might be due to: 1) reduced concentration of effective peptide bonds available for hydrolysis; 2) enzyme or product inhibition; and 3) inactivation of enzyme (Gonzàlez-Tello et al., 1994).

In order to determine $\mathrm{DH}$ equation constants, $\mathrm{DH}$ changes were measured during time and then $a$ and $b$ constants were calculated using Equation 7. By plotting $\mathrm{a}$ and $\mathrm{b}$ against enzyme to substrate ratio, their equations was also obtained (Table 4). The results indicated that $\mathrm{b}$ changed slightly with an average of 0.099 for total protein, 0.1061 for myofibrillar protein and 0.1107 for sarcoplasmic protein. The a parameter reduced and increased by increased substrate and enzyme concentrations, respectively. Therefore, a linear relation was observed between a and $\mathrm{E}_{0} / \mathrm{S}_{0}$ as shown in Figure 6 and following equation:

$D H=\frac{1}{b} \ln (1+a b t)$

$\mathrm{a}=7.8434\left[\mathrm{E}_{0}\right] /\left[\mathrm{S}_{0}\right]+0.1508$ Total protein;

$\mathrm{a}=9.437\left[\mathrm{E}_{0}\right] /\left[\mathrm{S}_{0}\right]+0.0885$ Myofibrillar protein;

Sarcoplasmic protein $\mathrm{a}=9.0436\left[\mathrm{E}_{0}\right] /\left[\mathrm{S}_{0}\right]+0.1118$. 


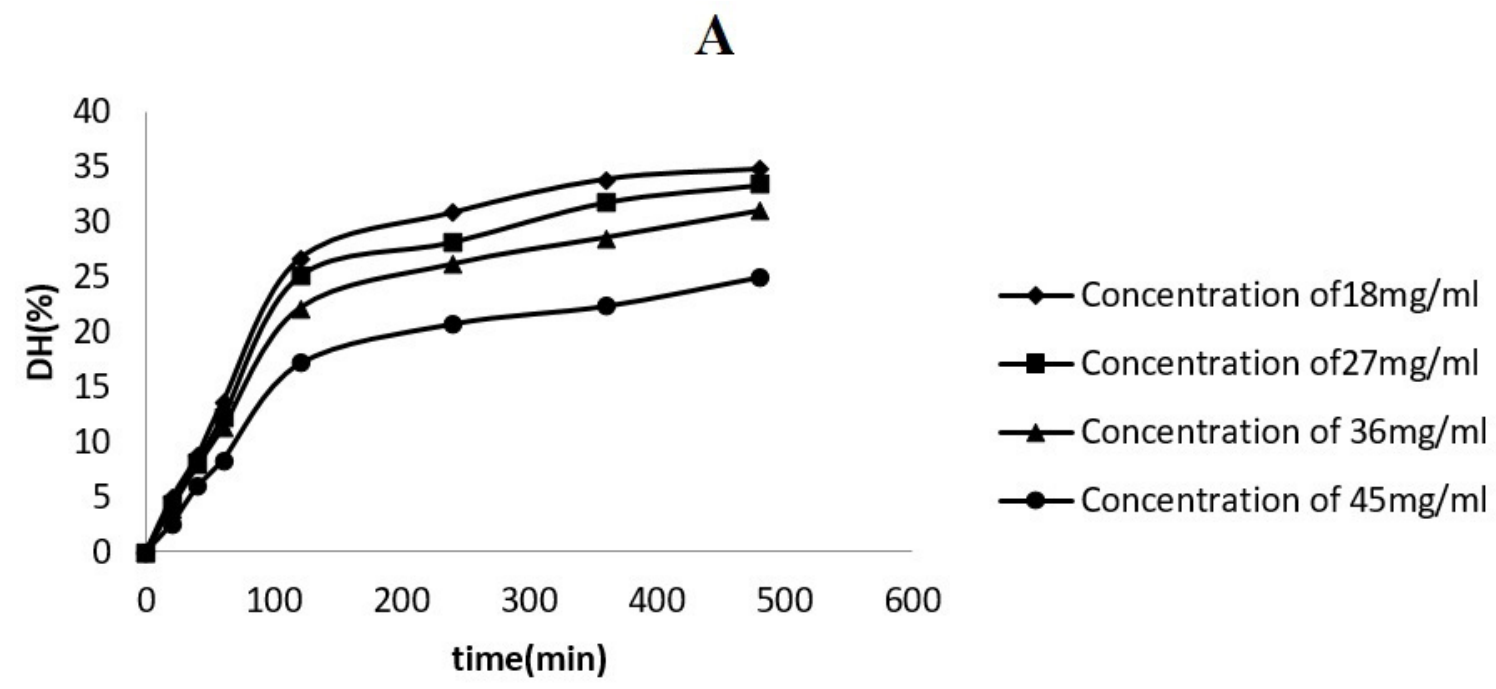

B

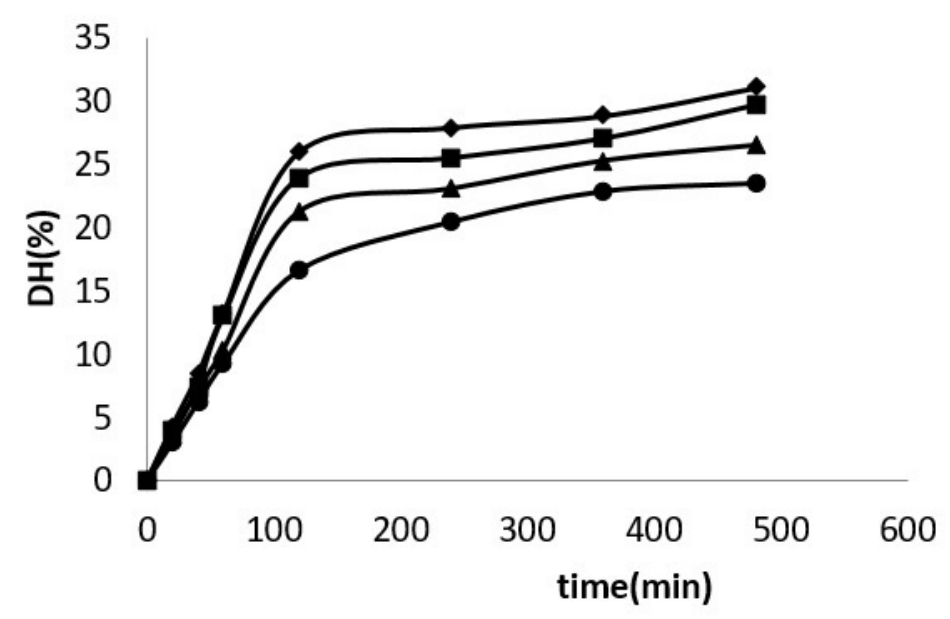

$\multimap$ Concentration of $18 \mathrm{mg} / \mathrm{ml}$

$\rightarrow-$ Concentration of $27 \mathrm{mg} / \mathrm{ml}$

$\neg$ Concentration of $36 \mathrm{mg} / \mathrm{ml}$

$\rightarrow$ Concentration of $45 \mathrm{mg} / \mathrm{ml}$

C

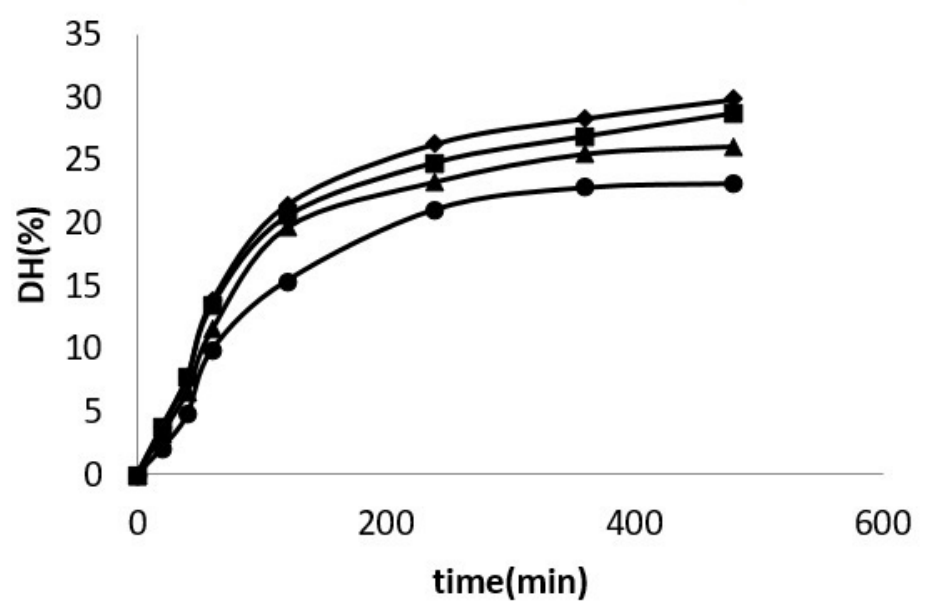

$\longrightarrow$ Concentration of $18 \mathrm{mg} / \mathrm{ml}$

$\rightarrow-$ Concentration of $27 \mathrm{mg} / \mathrm{ml}$

$\longrightarrow$ Concentration of $36 \mathrm{mg} / \mathrm{ml}$

$\rightarrow-$ Concentration of $45 \mathrm{mg} / \mathrm{ml}$

Figure 4. Effect of different substrate concentrations on the degree of hydrolysis during time, (A) total protein; (B) myofibrillar protein; (C) sarcoplasmic protein. 


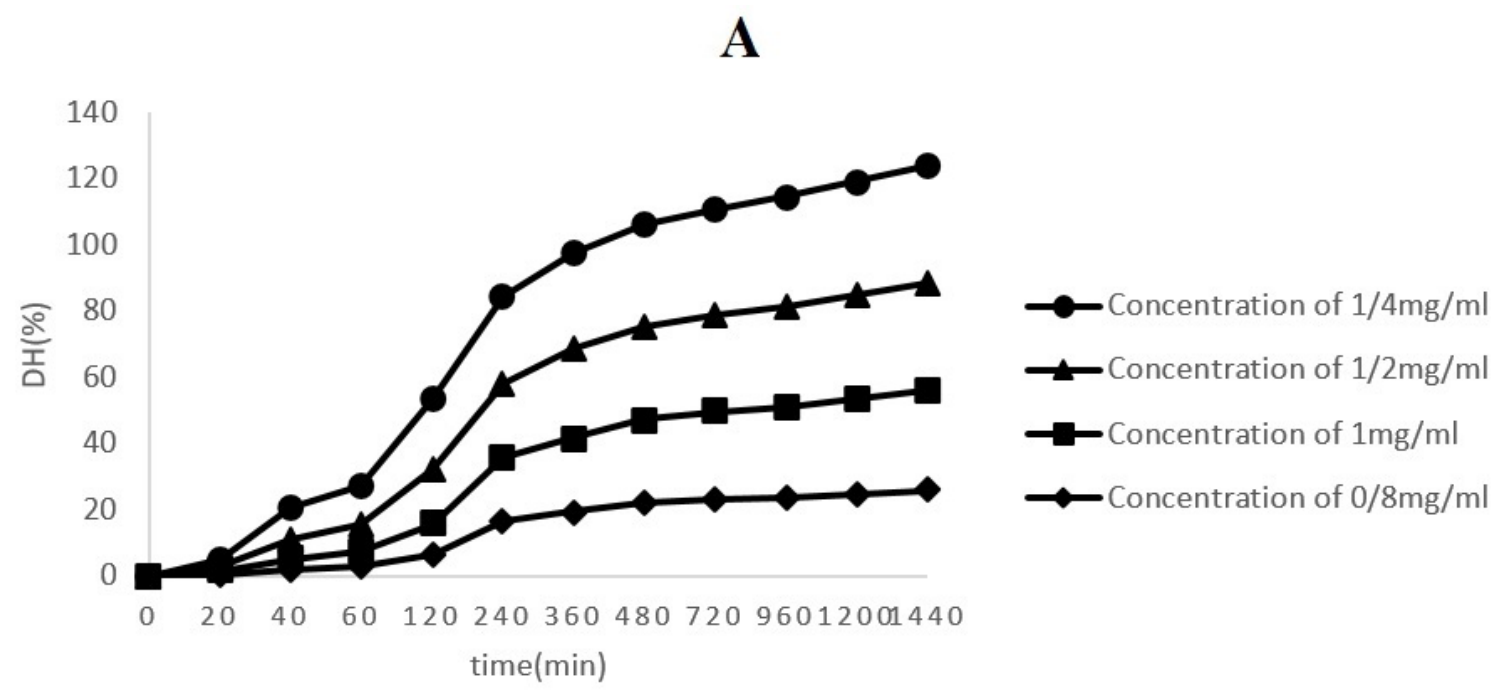

B

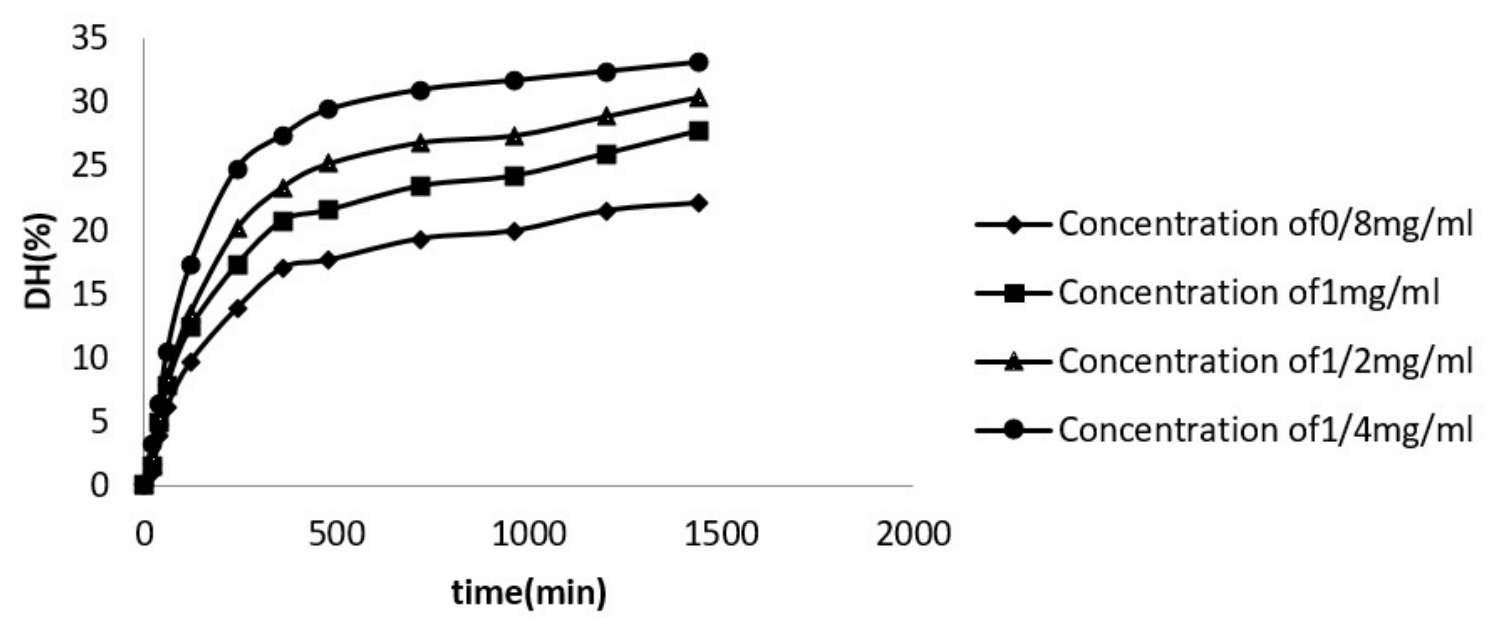

C

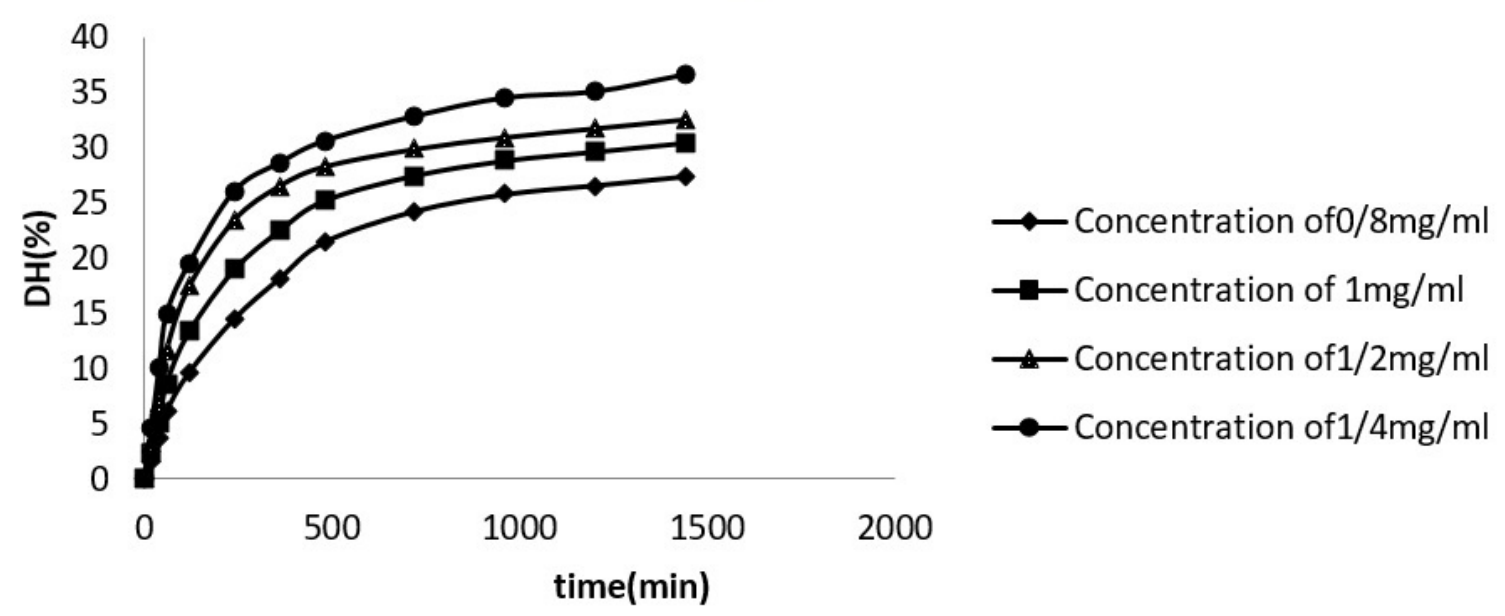

Figure 5. Effect of different enzyme concentrations on the degree of hydrolysis during time, (A) total protein; (B) myofibrillar protein; (C) sarcoplasmic protein. 
A

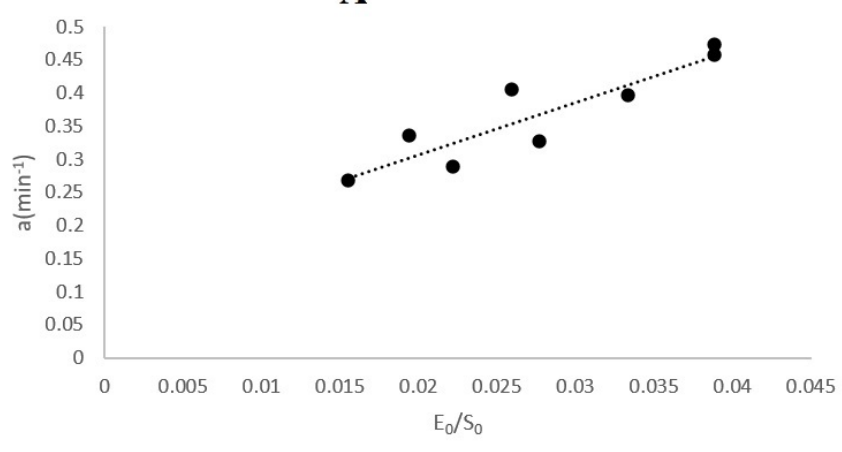

B

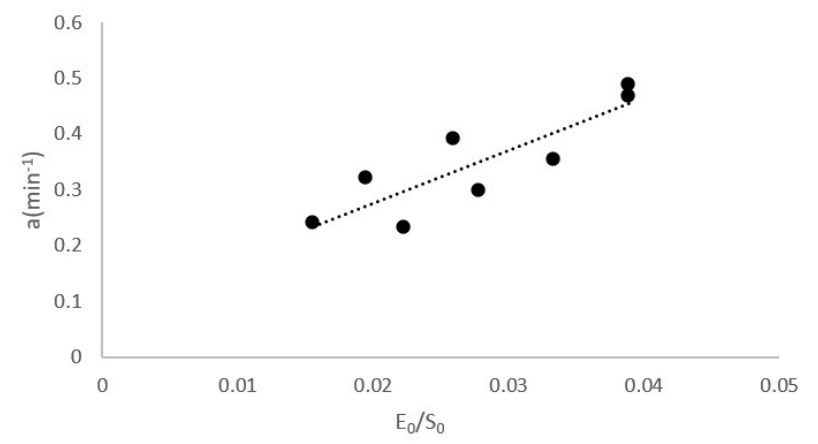

C

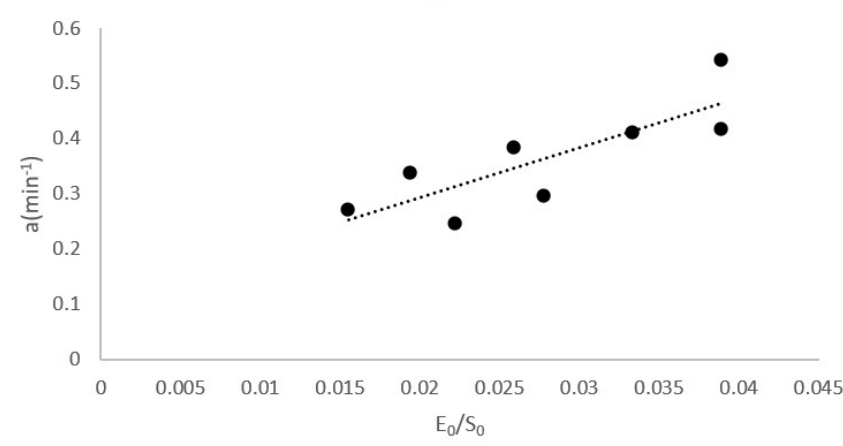

Figure 6. Changes in a parameter against different $\mathrm{E}_{0} / \mathrm{S}_{0},(\mathrm{~A})$ total protein; (B) myofibrillar protein; (C) sarcoplasmic protein.

Eight equations were used to determine Michaelis-Menten equation parameters (Equation 8):

$V=\frac{V_{m}[S]}{K+[S]}$

where: $\mathrm{V}_{0}$ or $\mathrm{V}$ is initial reaction rate $(\mu \mathrm{mol} \mathrm{L}-1 \mathrm{~min}-1)$; $[\mathrm{S}]$ is substrate concentration $(\mathrm{mM}) ; \mathrm{V}_{\max }$ is maximum rate $(\mathrm{mM})$; and $\mathrm{K}_{\mathrm{m}}$ is Michaelis constant which is expressed as concentration $(\mathrm{mg} / \mathrm{mL})$, in other words; $\mathrm{K}_{\mathrm{m}}$ is the substrate concentration at which the reaction rate is half of the $\mathrm{V}_{\max }, K_{m}=\frac{1}{2}\left(\mathrm{v}_{\max }\right)$.

Table 5 presents obtained values for $\mathrm{K}_{\mathrm{m}}, \mathrm{V}_{\max }$ and $\mathrm{K}_{\mathrm{s}}$. According to the results, $\mathrm{V}_{\max }$ was highest for total protein and lowest for sarcoplasmic protein. Parameter $\mathrm{K}_{\mathrm{m}}$ represents proximate tendency
Table 4. DH equation constant for chicken meat

\begin{tabular}{|c|c|c|c|c|c|c|c|c|}
\hline \multirow{2}{*}{$\mathrm{E}_{0}$} & \multirow{2}{*}{$\mathrm{S}_{0}$} & \multirow{2}{*}{$\mathrm{E}_{0} / \mathrm{S}_{0}$} & \multicolumn{2}{|c|}{$\mathrm{T}$} & \multicolumn{2}{|c|}{$\mathrm{M}$} & \multicolumn{2}{|c|}{ S } \\
\hline & & & $\mathrm{a}$ & $\mathrm{b}$ & $\mathrm{a}$ & b & $\mathrm{a}$ & $\mathrm{b}$ \\
\hline 0.7 & 18 & 0.039 & 0.457 & 0.077 & 0.489 & 0.095 & 0.416 & 0.095 \\
\hline 0.7 & 27 & 0.026 & 0.405 & 0.079 & 0.393 & 0.099 & 0.382 & 0.102 \\
\hline 0.7 & 36 & 0.019 & 0.335 & 0.086 & 0.323 & 0.106 & 0.337 & 0.103 \\
\hline 0.7 & 45 & 0.016 & 0.268 & 0.101 & 0.242 & 0.112 & 0.270 & 0.108 \\
\hline 0.8 & 36 & 0.022 & 0.288 & 0.112 & 0.233 & 0.117 & 0.245 & 0.113 \\
\hline 1 & 36 & 0.027 & 0.327 & 0.103 & 0.299 & 0.110 & 0.296 & 0.119 \\
\hline 1.2 & 36 & 0.033 & 0.396 & 0.112 & 0.354 & 0.106 & 0.411 & 0.121 \\
\hline 1.4 & 36 & 0.038 & 0.471 & 0.118 & 0.469 & 0.101 & 0.542 & 0.125 \\
\hline
\end{tabular}

$\mathrm{E}_{0}$ : Enzyme concentration, $\mathrm{S}_{0}$ : substrate concentration, $\mathrm{E}_{0} / \mathrm{S}_{0}$ : Enzyme to Substrate ratio, a,b: parameter, T:total protein M: myofibrillar protein $\mathrm{S}$ : sarcoplasmic protein

Table 5. Enzyme kinetics parameters

\begin{tabular}{ccccc}
\hline & & $\mathrm{T}$ & $\mathrm{M}$ & $\mathrm{S}$ \\
\hline $\boldsymbol{V}=\frac{\boldsymbol{V}_{\boldsymbol{m}}[\boldsymbol{S}]}{\boldsymbol{K}+[\boldsymbol{S}]}$ & $\mathrm{V}_{\mathrm{m}}$ & 0.11 & 0.108 & 0.095 \\
& $\mathrm{~K}$ & 28.05 & 28.55 & 33.25 \\
& $\mathrm{R}^{2}$ & 0.99 & 0.98 & 0.98 \\
\hline
\end{tabular}

$\mathrm{V}_{\mathrm{m}}$ : maximum reaction velocity, K: Michaelis constant, T:total protein M: myofibrillar protein S: sarcoplasmic protein.

of the enzyme and substrate for binding, the lower the value, the higher the tendency. According to Table $1, \mathrm{~V}_{\max }$ was higher in total protein than in sarcoplasmic and myofibrillar proteins, suggesting higher enzyme activity in total protein. The value of $V_{0}$ when enzyme is fully saturated with substrate is called maximum velocity (Vmax). Michaelis constant $(\mathrm{Km})$ shows the affinity of enzyme towards the substrate and is corresponds to half of Vmax. These kinetic parameters of an enzymatic reaction provide information about specificity and mechanism of reaction. Higher Km means enzyme needs higher concentration of substrate with lower affinity toward substrate in an enzymatic reaction (Shargel et al., 2005; Taylor \& Diers-Caviness, 2003). According to the Michaels and Menton equation can be said that the more active enzyme and its affinity with the substrate increases the rate of reaction and $\mathrm{km}$ is smaller. The lower $\mathrm{Km}$ of the enzyme for total protein suggests that this protein is a better and suitable substrate for actinidine in this study.

Moreover, $\mathrm{K}_{\mathrm{m}}$ was lower in total protein, which indicates greater binding tendency of total protein and substrate, and consequently faster reaching to maximum activity $\left(\mathrm{V}_{\max }\right)$.

\section{Conclusion}

Given that the aim of this study was to provide tenderness in chicken meat, based on the results obtained, the hardness of samples, treated with the kiwi extract, decreased, the $a^{*}$ value decreased, and $\mathrm{L}^{*}$ increased. The increase in the time of hydrolysis increased the degree of hydrolysis, but the peptide chain length decreased. According to the obtained results, marination of meat with kiwifruit tenderizes the meat and improves its properties. Kinetics curves of the enzymatic reactions showed high rates 
of reactions at the beginning and reduced ones until a constant rate afterwards. The studied factors showed considerable impact on enzymatic hydrolysis. Kinetic equation protein enzymatic hydrolysis could properly model enzymatic reaction of chicken meat. Investigation of interaction of kinetic parameters and enzyme variables indicated that different enzyme and substrate concentrations did not affect $b$ parameter while positively affect a parameter.

\section{Acknowledgements}

Hereby, we would like to express our deepest thanks and appreciation to Chaharmahal and Bakhtiari (Shahrekord) Agricultural and Natural Resources Research and Education Center for providing us with laboratory facilities.

\section{References}

Adler-Nissen, J. (1986). Enzymic hydrolysis of food proteins. London: Elsevier Applied Science.

Afshar-Mohammadian, M., Rahimi-Koldeh, J., \& Sajedi, R. (2011). The comparison of protease activity and total protein in three cultivars of kiwifruit of Northern Iran during fruit development. Acta Physiologiae Plantarum, 33(2), 343-348. http://dx.doi.org/10.1007/ s11738-010-0553-3.

Aktaş, N., \& Kaya, M. (2001). The influence of marinating with weak organic acids and salts on the intramuscular connective tissue and sensory properties of beef. European Food Research and Technology, 213(2), 88-94. http://dx.doi.org/10.1007/s002170100329.

Amirpur, A. (2013). The study of the possibility of producing superadvantageous Gaz using traditional natural sweeteners (date juice, grape juice, and berry juice). Shahrekord Branch: Islamic Azad University.

Baek, H., \& Cadwallader, K. (1995). Enzymatic hydrolysis of crayfish processing by-products. Journal of Food Science, 60(5), 929-935. http://dx.doi.org/10.1111/j.1365-2621.1995.tb06264.x.

Berge, P., Ertbjerg, P., Larsen, L., Astruc, T., Vignon, X., \& Møller, A. (2001). Tenderization of beef by lactic acid injected at different times post mortem. Meat Science, 57(4), 347-357. http://dx.doi. org/10.1016/S0309-1740(00)00110-8. PMid:22061706.

Beyki Bandarabadi, M. (2005). The quality of chicken meat and the phenomenon of pale, soft, and oozing meat. Ira: Tabirestan. Retrieved from http://www.tabirestan.com/index.php?id_title=12\&id_article $=14798$

Bourne, M. (2002). Texture, viscosity, and food. In M. Bourne, Food texture and viscosity: concept and measurement. San Diego: Academic Press. http://dx.doi.org/10.1016/B978-012119062-0/50001-2.

Brookfield. (2007). Brookfield CT3 texture analyzer. Toronto.

Burke, R., \& Monahan, F. (2003). The tenderisation of shin beef using a citrus juice marinade. Meat Science, 63(2), 161-168. http://dx.doi. org/10.1016/S0309-1740(02)00062-1. PMid:22062175.

Cao, W., Zhang, C., Hong, J., \& Ji, H. (2008). Response surface methodology for autolysis parameters optimization of shrimp head and amino acids releasedduring autolysis. Food Chemistry, 109(1), 176-183. http://dx.doi.org/10.1016/j.foodchem.2007.11.080. PMid:26054279.

Carne, A., \& Moore, C. H. (1978). The amino acid sequence of the tryptic peptides from actinidin, a proteolytic enzyme from the fruit of Actinidia chinensis. The Biochemical Journal, 173(1), 73-83. http:// dx.doi.org/10.1042/bj1730073. PMid:687380.

Chueachuaychoo, A., Wattanachant, S., \& Benjakul, S. (2011). Quality characteristics of raw and cooked spent hen Pectoralis major muscles during chilled storage: effect of salt and phosphate. International Food Research Journal, 18, 601-613.

Claeys, E., Uytterhaegen, L., Buts, B., \& Demeyer, D. (1995). Quantification of beef myofibrillar proteins. Meat Science, 39(2), 177-193. http:// dx.doi.org/10.1016/0309-1740(94)P1819-H. PMid:22059824.

El-Gharbawi, M., \& Whitaker, J. (2006). Factors affecting enzymatic solubilization of beef proteins. Journal of Food Science, 28(2), 168172. http://dx.doi.org/10.1111/j.1365-2621.1963.tb00177.x.

Englund, P., King, T., Craig, L., \& Walti, A. (1968). Ficin. I. Its isolation and characterization. Biochemistry, 7(1), 163-175. http://dx.doi. org/10.1021/bi00841a021. PMid:5758541.

Ergezer, H., \& Gokce, R. (2011). Comparison of marinating with two different types of marinade on some quality and sensory characteristics of turkey breast meat. Journal of Animal and Veterinary Advances, 10(1), 60-67. http://dx.doi.org/10.3923/javaa.2011.60.67.

Fatemi, H. (2016). Food chemistry. Tehran: Sahami Enteshatr.

Garg, V., \& Mendiratta, S. (2006). Studies on tenderization and preparation of enrobed pork chunks in microwave oven. Meat Science, 74(4), 718726. http://dx.doi.org/10.1016/j.meatsci.2006.06.003. PMid:22063229.

Gault, N. (1985). The relationship between water-holding capacity and cooked meat tenderness in some beef muscles as influenced by acidic conditions below the ultimate $\mathrm{pH}$. Meat Science, 15(1), 15-30. http://dx.doi.org/10.1016/0309-1740(85)90071-3. PMid:22056073.

Gilman, A., Philips, F. S., Koelle, E. S., Allen, R. P., \& St. John, E. (1946). The metabolic reduction and nephrotoxic action of tetrathionate in relation to a possible interaction with sulfhydryl compounds. The American Journal of Physiology, 147(1), 115-126. http://dx.doi. org/10.1152/ajplegacy.1946.147.1.115. PMid:21000729.

Goli, T., Abi Nakhoul, P., Zakhia-Rozis, N., Trystram, G., \& Bohuon, P. (2007). Chemical equilibrium of minced turkey meat in organic acid solutions. Meat Science, 75(2), 308-314. http://dx.doi.org/10.1016/j. meatsci.2006.07.016. PMid:22063663.

Gonzàlez-Tello, P., Camacho, F., Jurado, E., Páez, M. P., \& Guadix, E. M. (1994). Enzymatic hydrolysis of whey proteins: I. kinetic models. Biotechnology and Bioengineering, 44(4), 523-528. http://dx.doi. org/10.1002/bit.260440415. PMid:18618786.

Ha, M., Bekhit, A.-D., Carne, A., \& Hopkins, D. (2012). Characterisation of commercial papain, bromelain, actinidin and zingibain protease preparations and their activities toward meat proteins. Food Chemistry, 134(1), 95-105. http://dx.doi.org/10.1016/j.foodchem.2012.02.071.

Han, J., Morton, J., Bekhit, A., \& Sedcole, J. (2009). Pre-rigor infusion with kiwifruit juice improves lamb tenderness. Meat Science, 82(3), 324-330. http://dx.doi.org/10.1016/j.meatsci.2009.02.003. PMid:20416722.

Hellyer, J. (2004). Quality testing with instrumental texture. LPI.

Hevia, P., Whitaker, J., \& Olcott, H. (1976). Solubilization of a fish protein concentrate with proteolytic enzymes. Journal of Agricultural and Food Chemistry, 24(2), 383-385. http://dx.doi.org/10.1021/ jf60204a048. PMid:1254819.

Hinkle, J., Calkins, C., Mello, S. A. Jr., Senaratne, L., \& Pokharel, S. (2010). Acid marination for tenderness enhancement of the beef bottom round. Nebraska Beef Cattle Reports, 93, 128-130.

Joo, S., Kauffman, R. G., Kim, B. C., \& Park, G. B. (1999). The relationship of sarcoplasmic and myofibrillar protein solubility to colour and water-holding capacity in porcine longissimus muscle. Meat Science, 52(3), 291-297. http://dx.doi.org/10.1016/S0309-1740(99)00005-4. PMid:22062578.

Kemp, C., \& Parr, T. (2012). Advances in apoptotic mediated proteolysis in meat tenderisation. Meat Science, 92(3), 252-259. http://dx.doi. org/10.1016/j.meatsci.2012.03.013. PMid:22546815. 
Ketnawa, S., \& Rawdkuen, S. (2011). Application of bromelain extract for muscle foods tenderization. Food and Nutrition Sciences, 2(5), 1-9. http://dx.doi.org/10.4236/fns.2011.25055.

Koak, J.-H., Kim, H.-S., Choi, Y., Baik, M.-Y., \& Kim, B.-Y. (2011). Characterization of a protease from over-matured fruits and development of a tenderizer using an optimization technique. Food Science and Biotechnology, 20(2), 485-490. http://dx.doi.org/10.1007/ s10068-011-0067-9.

Kowlessur, D., O’Driscoll, M., Topham, C., Templeton, W., Thomas, E., \& Brocklehurst, K. (1989). The interplay of electrostatic fields and binding interactions determining catalytic-site reactivity in actinidin: a possible origin of differences in the behaviour of actinidin and papain. The Biochemical Journal, 259(2), 443-452. http://dx.doi. org/10.1042/bj2590443. PMid:2719659.

Kristinsson, H. (1998). Reaction kinetics, biochemical and functional properties of salmon muscle proteins hydrolyzed by different alkaline proteases. Washington: University of Washington.

Kristinsson, H., \& Rasco, B. (2000). Fish protein hydrolysates: production, biochemical, and functional properties. Critical Reviews in Food Science and Nutrition, 40(1), 43-81. http://dx.doi. org/10.1080/10408690091189266. PMid:10674201.

Lawrie, R., \& Ledward, D. (2006). Lawrie's meat science (7th ed.). Cambridge: Woodhead Publishing. http://dx.doi.org/10.1533/9781845691615.

Lewis, D., \& Luh, B. S. (1988). Application of actinidin from kiwifruit to meat tenderization and characterization of beef muscle protein hydrolysis. Journal of Food Biochemistry, 12(3), 147-158. http:// dx.doi.org/10.1111/j.1745-4514.1988.tb00368.x.

Liaset, B., Lied, E., \& Espe, M. (2000). Enzymatic hydrolysis of byproducts from the fish-filleting industry: chemical characterisation and nutritional evaluation. Journal of the Science of Food and Agriculture, 80(5), 581-589. http://dx.doi.org/10.1002/(SICI)10970010(200004)80:5<581::AID-JSFA578>3.0.CO;2-I.

Linder, M., Fanni, J., Parmentier, M., Sergent, M., \& Phan-Tan-Luu, R. (1995). Protein recovery from veal bones by enzymatic hydrolysis. Food Science, 60(5), 949-952. http://dx.doi.org/10.1111/j.1365-2621.1995. tb06268.x.

Mahmoud, M., Malone, W. T., \& Cordle, C. T. (1992). Enzymatic hydrolysis of casein. effect of degree of hydrolysis on antigenicity and physical properties. Journal of Food Science, 57(5), 1223-1229. http://dx.doi.org/10.1111/j.1365-2621.1992.tb11304.x.

Marambe, P., Shand, P., \& Wanasundara, J. (2008). An in-vitro investigation of selected biological activities of hydrolysed flaxseed (Linum usitatissimum L.) proteins. Journal of the American Oil Chemists' Society, 85(12), 1155-1164. http://dx.doi.org/10.1007/ s11746-008-1293-Z.

Molina, I., \& Toldrá, F. (1992). Detection of proteolytic activity in microorganisms isolated from dry cured ham. Journal of Food Science, 57(6), 1308-1310. http://dx.doi.org/10.1111/j.1365-2621.1992. tb06843.x.

Mortazavi, A., Salary, R., \& Zia ul Haq, H. (2007). Modeling of food processes. Mashhad: Mashhad Ferdowsi University.

Motamedzadegan, A., Shahidi, F., Mortazavi, S. A., Pourazarang, H., Hamzeh, S. H., Shahidi Yasaghi, S. A., Ghorbani Hasan Saraei, A., \& Khanipour, E. (2009). Effect of kilka fish myofibrillar protein hydrolysis by papain on peptide chain length and degree of hydrolysis. Journal of Agricultural Sciences and Natural Resources, 16(3), 172-181.

Mutilangi, W. A. M., Panyam, D., \& Kilara, A. (1995). Hydrolysates from proteolysis of heat-denatured whey proteins. Food Science, 60(5), 1104-1109. http://dx.doi.org/10.1111/j.1365-2621.1995.tb06302.x.
Naveena, B. M., Mendiratta, S. K., \& Anjaneyulu, A. S. (2004). Tenderization of buffalo meat using plant proteases from Cucumis trigonus Roxb (Kachri) and Zingiber officinale roscoe (Ginger rhizome). Meat Science, 68(3), 363-369. http://dx.doi.org/10.1016/j. meatsci.2004.04.004. PMid:22062404.

Noordahr, R. (1998). Meat science and technology (3rd ed.). Tehran: Tehran University Press.

Önenc, A., Serdaroglu, M., \& Abdraimov, K. (2004). Effect of various additives to marinating baths on some properties of cattle meat. European Food Research and Technology, 218(2), 114-117. http:// dx.doi.org/10.1007/s00217-003-0828-7.

Ovissipour, M., Benjakul, S., Safari, R., \& Motamedzadegan, A. (2010). Fish protein hydrolysates production from yellowfin tuna Thunnus albacares head using Alcalase and Protamex. International Aquatic Research., 2(2), 87-95.

Page, J., Wulf, D., \& Schwotzer, T. (2001). A survey of beef muscle color and pH. Journal of Animal Science, 79(3), 678-687. PMid:11263828.

Paul, W., Amiss, J., Try, R., Praekelt, U., Scott, R., \& Smith, H. (1995). Correct processing of the kiwifruit protease actinidin in transgenic tobacco requires the presence of the C-terminal propeptide. Plant Physiology, 108(1), 261-268. http://dx.doi.org/10.1104/pp.108.1.261. PMid:7784505.

Polaina, J., \& MacCabe, A. (2007). Industrial enzymes structure, function and applications. Netherlands: Springer. http://dx.doi.org/10.1007/14020-5377-0.

Qian, J., Zhang, H., \& Liao, Q. (2011). The properties and kinetics of enzymatic reaction in the process of the enzymatic extraction of fish oil. Journal of Food Science and Technology, 48(3), 280-284. http:// dx.doi.org/10.1007/s13197-010-0128-8. PMid:23572747.

Quaglia, G., \& Orban, E. (1987). Influence of the degree of hydrolysis on the solubility of the protein hydrolysates from sardine (Sardina pilchardus). Journal of the Science of Food and Agriculture, 38(3), 271-276. http://dx.doi.org/10.1002/jsfa.2740380311.

Rawdkuen, S., Jaimakreu, M., \& Benjakul, S. (2013). Physicochemical properties and tenderness of meat samples using proteolytic extract from Calotropis procera latex. Food Chemistry, 136(2), 909-916. http://dx.doi.org/10.1016/j.foodchem.2012.08.077. PMid:23122144.

Samejima, K., Choe, I.-S., Ishioroshi, A., \& Hayakawa, A. (1991). Hydrolysis of muscle proteins by actinidin (kiwifruits protease). Nippon Shokuhin Kogyo Gakkaishi, 38(9), 817-821. http://dx.doi. org/10.3136/nskkk1962.38.817.

Serdaroğlu, M., Abdraimov, K., \& Önenç, A. (2007). The effects of marinating with citric acid solutions and grapefruit juice on cooking and eating quality of Turkey breast. Journal of Muscle Foods, 18(2), 162-172. http://dx.doi.org/10.1111/j.1745-4573.2007.00074.x.

Shahidi, F., Han, X., \& Synowiecki, J. (1995). Production and characteristics of protein hydrolysates from capelin (Mallotus villosus). Food Chemistry, 53(3), 285-293. http://dx.doi.org/10.1016/0308-8146(95)93934-J.

Shargel, L., Wu-Pong, S., \& Yu, A. B. C. (2005). Applied biopharmaceutics and pharmacokinetics (5th ed.). New York: McGraw-Hill.

Souissi, N., Bougatef, A., Triki-Ellouz, Y., \& Nasr, M. (2007). Biochemical and functional properties of sardinella (Sardinella aurita) by-product hydrolysates. Food Technology and Biotechnology, 45(2), 87-194.

Sullivan, G., \& Calkins, C. (2010). Application of exogenous enzymes to beef muscle of high and low-connective tissue. Meat Science, 85(4), 730-734. http://dx.doi.org/10.1016/j.meatsci.2010.03.033. PMid:20416788. 
Szczesniak, A. (2002). Texture is a sensory property. Food Quality and Preference, 13(4), 215-225. http://dx.doi.org/10.1016/S09503293(01)00039-8.

Tarté, R. (2009). Ingredients in meat products: properties, functionality and applications. New York: Springer. http://dx.doi.org/10.1007/9780-387-71327-4.

Taylor, W. J., \& Diers-Caviness, M. H. (2003). A textbook of the clinical application of therapeutic drug monitoring. Irving: Diagnostic Division,Abbott Laboratories.

Toohey, E. S., Kerr, M. J., Van de Ven, R., \& Hopkins, D. L. (2011). The effect of a kiwi fruit based solution on meat traits in beef $\mathrm{m}$. semimembranosus (topside). Meat Science, 88(3), 468-471. http:// dx.doi.org/10.1016/j.meatsci.2011.01.028. PMid:21345602.
Wada, Hosaka, M., Nakazawa, R., Kobayashi, Y., \& Hasegawa, T. (2004). The solubilization of unheated cattle achilles tendon with actinidin under neutral and acidic conditions. Food Science and Technology Research, 10(1), 35-37. http://dx.doi.org/10.3136/fstr.10.35.

Wada, M., Suzuki, T., Yaguti, Y., \& Hasegawa, T. (2002). The effects of pressure treatments with kiwi fruit protease on adult cattle semitendinosus muscle. Food Chemistry, 78(2), 167-171. http:// dx.doi.org/10.1016/S0308-8146(01)00395-8.

Zardetto, S., \& Dalla Rosa, M. (2006). Study of the effect of lamination process on pasta by physical chemical determination and near infrared spectroscopy analysis. Journal of Food Engineering, 74(3), 402-409. http://dx.doi.org/10.1016/j.jfoodeng.2005.03.029. 